\title{
Reducing the environmental health risk of the vulnerable group in a developing country: a case study of metropolitan Lagos
}

\author{
I. Nwokoro \\ Department of Urban and Regional Planning, \\ University of Lagos, Nigeria
}

\begin{abstract}
The household, workplace, outdoor and transportation environments pose risks to health in a number of different ways, from the poor quality of the air many people breathe to the hazards we face as a result of climate change. This problem is exacerbated by the high population growth rate of Metropolitan Lagos. This puts a lot of pressure on existing infrastructural and social services which further degrade the environment. Unfortunately, the poor are the most vulnerable to these health and environmental hazards. This paper focused on the social and environmental health risk factors associated with vulnerable groups in Metropolitan Lagos. Specifically, this paper reports how these factors affect the health conditions of these groups of people. Metropolitan Lagos is stratified into various neighbourhoods according to income level and density. Three low income/high density areas were selected for study. The direct observation, administration of questionnaire and Focus Group Discussion (FGD) methods of data collection were employed in addition to the use of secondary based facility data. Information were sought on environmental risk variables like the quality of water, sanitary conditions, refuse disposal types, drainage conditions, sources and intensity of air pollution and sources of energy for cooking. These variables were correlated against health indexes like morbidity and mortality. Results show a strong association between environmental factors and the health status of people especially the poor in the study area.

Keywords: environmental health factors, metropolitan Lagos, vulnerable group, health hazards, mortality, low income communities, air pollution, Bariga, Agege, Ajegunle.
\end{abstract}




\section{Introduction}

The environment is a composite of behavioral settings which greatly affects our health. Environmental factors that affect health are in turn linked to underlying pressures on the environment. These pressures are a result of intense urbanization witnessed by most developing countries especially, Metropolitan Lagos. In a recent United Nations Development Programme (UNDP) [1] study, Metropolitan Lagos is presently estimated to be 16.86 and is expected to hit the 24.5 million population mark and thus be among the ten most populous cities in the world by the year 2015. This is indeed frightening, considering the small size of the state put at $300 \mathrm{sqkm}$ and the type of density just stated, the weak infrastructural base to support such a huge population and, the current economic growth rate which is below $13 \%$. This is strongly supported by the WHO/UNICEF Global Water Supply and Sanitation Assessment [2]. Exposure prevalence study which concluded that, overall, $99.8 \%$ of deaths associated with risk factors are in developing countries, and $90 \%$ are deaths of children.

However, these hazards have changed from the traditional factors often caused by poverty and insufficient development, and include lack of safe drinking water, inadequate sanitation and waste disposal methods to more modern hazards which are more global. These include; lack of coordinated health and environmental safeguards, air pollution, over-consumption of natural resources, widespread water pollution, population sprawl, intensive industrial development, climate change, and stratospheric ozone depletion. Each of these environmental hazards is associated with a variety of economic and social determinants of health. Unfortunately, air pollution has remained a major problem in Metropolitan Lagos. Major sources such as automobiles and dieselfired electricity generators contribute to the choking air plagued by daily smog shrouding the skyline of the central city. Studies carried out by the Federal Environmental Protection Agency (FEPA) [3] show a moderate-to-high concentration of pollutants such as carbon monoxide, sulphur dioxide, nitrogen oxides, organic acids and hydrocarbons in the atmosphere, the majority of which come from rickety and un-serviced automotive engines and industries. At the same time, however, irregular power supply in Lagos has prompted residents to turn to diesel-fired electricity generators, which add to the air pollution with their thick, dark smoke when they start operating in the event of the frequent power cuts. In addition to this is indoor air pollution which comes mostly from soot from the burning of wood, dung, crop residues and coal for cooking and heating. A study by Iwugoh et al [4] shows that water resources in Lagos for domestic, industries and commercial is becoming scarce as a result of pollution of water bodies by wastewater, which contains heavy metals, bacteria (pathogenic) etc. Closely associated with this is flooding which is a serious problem in Lagos metropolis caused by poor drainage systems, the relatively high water table and the flat topography which retards the flow of surface water run-off and prevents rapid discharge into the sea. The aim of this paper, therefore, is to identify and evaluate most of the environmental health risk factors that affect the vulnerable group in Metropolitan Lagos with a view to finding solutions to ameliorate them. 


\section{The setting}

The Lagos metropolitan area comprises $88.7 \%$ of Lagos state, a total of $19.87 \mathrm{sq} . \mathrm{km}$. Presently, the population density in the built-up Metropolitan area is 20,000 persons/sq km as reported in Lagos State Economic Summit [5]. The population of Lagos metropolitan area earlier stated is about $11.2 \%$ of Nigeria's overall population. However, based on its high urbanization rates and its dense population, the poverty level in Metropolitan Lagos is very high. Records from the Federal Office of Statistics [6] indicate that about $53 \%$ of the population lives below the poverty line. Similarly, in Lagos Metropolis, there is a direct relationship between poverty and household size.

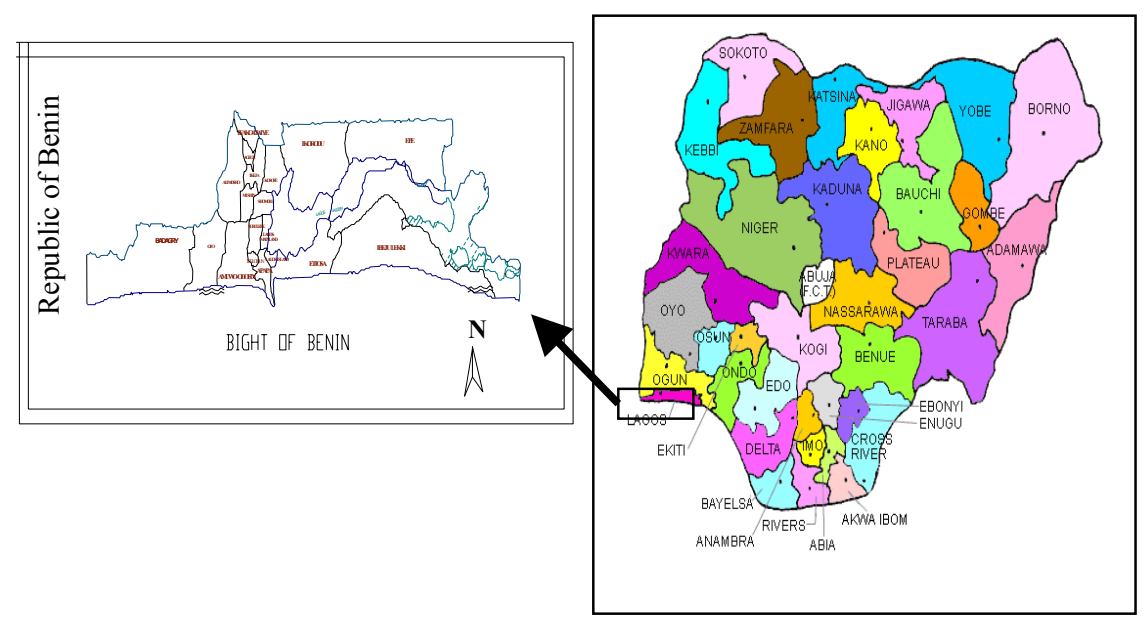

Figure 1: $\quad$ Map of Nigeria showing Metropolitan Lagos.

Lagos metropolis is stratified into various neighbourhoods according to income levels. The income indicators used include some socio-economic characteristics of the neighbourhoods, for example, type of accommodation (duplex, bungalow, Flat, rooming), quality of buildings(good, dilapidated), monthly income of household etc. The Income groups identified include; Low income/high density, Medium income/medium density and high income/low density. Based on this, three low income neighbourhoods were randomly selected for study. They are Bariga, Agege and Ajegunle. These low income communities are among the nine urban blighted areas in Metropolitan Lagos. The NPC 1991 population figures for the different slum areas are Bariga 90,839, Agege 19,741 and Ajegunle, 191,430. They have similar characteristics which include very low average monthly income of between N7,500 to N15,000 (\$60 $\$ 120$ ), one room per household who are mostly tenants sharing housing facilities like bathroom, kitchen and toilet. The average household sizes are 7, 6 and 10 for Bariga, Agege and Ajegunle respectively. In terms of infrastructural facilities, most of their roads are not tarred, with blocked drainages and surroundings 
littered with refuse dumps. These often exacerbate flooding conditions especially in Bariga and Ajegunle areas.

\section{Literature review}

According to United States Agency for International Development (USAID) [7] study, natural environmental resources and the quality of its air, water, and study soil are severely threatened. The report found that increasing poverty, high population growth and migration, especially into urban areas, and political/institutional constraints are the underlying causes for environmental degradation in the country. These combinations of expanding population and increasing poverty puts increasingly severe demand upon the natural environment, the institutional structures and the resources available to manage them. These are all epitomized in Metropolitan Lagos.

The greatest degradation of the urban environment in the Third World is not merely pollution, erosion, mismanagement of waste, and the depletion and deterioration of resources, but rather it is the degraded and immensely impoverished quality of life, particularly for the majority of urban dwellers. According to the World Resources Institute (WRI)[8] about two billion hectares of soil- equal to 15 percent of the Earth's land cover - is already degraded..

Unfortunately, the poor are the most vulnerable to health and environmental hazards. Poor people are forced to overuse environmental resources to survive, and this impoverishing of the environment again threatens their survival. Accordingly, World Bank Report [9] defined poverty as 'increased vulnerability to environmental degradation or loss of access to natural resources, to employment scarcity, to property loss, to disease and ill health". Factors of vulnerability are for example poverty, illness and disabilities, age, gender, and limited access to resources.

Brundtland [10] noted the six major classes of environmental risks to include inadequate access to safe drinking water, poor hygiene and sanitation, inadequate water resource management, air pollution (indoor and outdoor), chemical hazards and unintentional injuries.

He further reports that in 2000, an estimated 1.1 billion people lacked access to an improved water source. Presently, around 2.4 billion people around the world do not have access to any type of improved sanitation facilities and that mosquitoes and worms are often the result of inadequate water resource management. Brundtland, also notes that air pollution, whether indoors from fuel consumption or tobacco smoke or outdoors from traffic and industrial pollution, is a serious risk factor for respiratory disease, a major contributor to ill-health among children around the world. Chemical hazards in the form of pollutants from unregulated industries, heavy traffic or toxic waste sites compound the hazards children are exposed to. Chronic exposure to certain chemicals has been linked to damage to the nervous system and may harm reproductive function and child development. Lastly, unintentional injuries comprising traffic injuries, poisonings, falls, burns and drowning all pose grave risks to children. 
Similarly, air pollution has become a serious risk factor for respiratory disease and a major contributor to ill-health among children around the world.

Environmental factors that affect health are in turn linked to underlying pressures on the environment, which are determined by such driving forces as: Poverty and economic mobility, population dynamics, threat of violence to children in all environments, urbanization: density and transportation, social and cross-cultural diversity, science and technology education, or lack of household wastes, fresh water land use and agricultural environment, Industrialization: external and internal, energy consumption and productions patterns, economic development and globalization of industry.

Akhtar [11], Adedoyin and Watt [12] and Egunjobi [13] have shown strong evidences of a direct relationship between the human environment and health. The World Health Organization has estimated that diseases carried by air and water affect more than 700million people a year. In cities, these diseases are exacerbated by poor sanitation and infrastructure. Biological pathogens have the most serious impact on human health. Crowded conditions, poor sanitation, inadequate water supplies, poor facilities for preparing and storing food, and inadequate hygiene contribute to biological pathogen-induced ill-health.

Brundtland [10] further noted that WHO studies show that around 2 million children die each year from acute respiratory infections alone, with indoor air pollution from cooking and heating putting them at serious risk. And diarrhea, a disease related to inadequate water and sanitation, is the second biggest child killer, claiming about 1.3 million children each year. Together, diarrhea, acute respiratory infections and malaria, all associated with environmental risk factors, kill more children worldwide than any other disease. Global warming will also increase the risks and danger of exposure to heat stress, especially in urban areas, which act as local heat traps because of their interference with air flow patterns, greater reflective surface area and local heat generation.

However, there are few studies that have tried to combine the traditional and modern environmental hazards as they affect the health of the poor in Nigeria. This paper attempts to fill this hiatus in knowledge.

\section{Methodology}

The choice of the three communities within Metropolitan Lagos has been discussed earlier. Collection of data involved direct observation method, administration of questionnaires and Focus Group Discussions (FGD). Secondary sources of data include health records especially on the cases of prevalent diseases in the Metropolitan Lagos sourced from the Lagos State Ministry of health, the Health Departments of the various local government areas where the communities belong to and one hospital (private or government owned) randomly selected from each of the communities within the study area.

To get a good and unbiased representation of the study area, all the streets in each of the communities were numbered. The average number of streets in each community is 40 . Thereafter, 10 streets from each community were randomly selected using the table of random numbers. Again in each community, all the 
houses belonging to the 10 selected streets were enumerated for sampling. 5 houses were randomly selected for sampling on each street. This means 50 questionnaires were administered in each community. In each selected building, all the households were numbered and one household selected using the table of random numbers. The questionnaire was administered to the head of the selected household.

Hypothesis to be tested is

$\mathrm{Ho}=$ There is no relationship between environmental factors and health conditions of individuals.

$\mathrm{Hi}=\quad$ There is a relationship between environmental factors and health conditions of individuals.

Variables of environmental factors (for example, lack of good drinking water, poor sanitation, drainage conditions etc.) were correlated against health conditions (for example, ill-health, and mortality). The Spearman Rank (Product Moment Rule) was used to test the level of significance at 95\% (0.05) level.

\section{Research results}

The research results are discussed under three broad sections showing the association of environmental conditions and health of the residents of the low income communities. These include environmental conditions, pollution, disease pattern and relationship between environmental and health conditions.

\subsection{Environmental conditions}

The environmental variables considered were water quality measured by the sources of water, sanitary conditions measured by toilet types, drainage condition measured by availability of drainage facilities and refuse disposal methods also measured by the type and availability.

Table 1: $\quad$ Source of water supply (if 1-3 = good, otherwise, poor).

\begin{tabular}{|l|l|l|l|l|l|l|l|}
\hline & & \multicolumn{2}{|c|}{ Bariga } & \multicolumn{2}{c|}{ Agege } & \multicolumn{2}{c|}{ Ajegunle } \\
\hline & Sources & No & $\%$ & No & $\%$ & No & $\%$ \\
\hline 1 & Piped water & 2.0 & 4.2 & 3.0 & 6.7 & 1.0 & 2.3 \\
\hline 2 & Borehole & 4.0 & 8.3 & 5.0 & 11.1 & 3.0 & 6.8 \\
\hline 3 & Spring & 0.0 & 0.0 & 0.0 & 0.0 & 0.0 & 0.0 \\
\hline 4 & Well & 9.0 & 18.8 & 11.0 & 24.4 & 10.0 & 22.7 \\
\hline 5 & Water vendors & 33.0 & 68.8 & 23.0 & 51.1 & 26.0 & 59.1 \\
\hline 6 & Stream/pond & 0.0 & 0.0 & 3.0 & 6.7 & 4.0 & 9.1 \\
\hline Total & & 48.0 & 100.0 & 45.0 & 100.0 & 44.0 & 100.1 \\
\hline
\end{tabular}

Table 1 shows that the most predominant source of water for the three communities is water vendors. These are private people who sell water in water tankers. $68.8 \%, 51.1 \%$ and $59.1 \%$ of respondents in Bariga, Agege and Ajegunle respectively patronize these vendors. The next major source of water is well (both deep and hand dug). The quality of these sources of water does not meet the World Health Organization (WHO) standards. They are often contaminated 
during the process of distribution. It is worrisome that only $4.2 \%, 6.7 \%$ and $2.3 \%$ of respondents in Bariga, Agege and Ajegunle have access to piped water. The few existing water piped mains are broken and lie inside dirty drainage channels. In summary only $12.5 \%, 17.8 \%$ and $9.15 \%$ of respondents in Bariga, Agege and Ajegunle respectively, have access to good sources of water. Poor water sources are often associated with water-borne diseases like cholera and diarrhoea which often lead to infant mortality as earlier corroborated in section 3 .

Table 2 shows that a sizeable proportion of the low income communities in Metropolitan Lagos still defecate in the bush, near refuse dumps and along water bodies. The most common type of toilet facility used by residents in these areas is the pit latrine which is very unhygienic. The water closet system is almost non-existent because of the absence of in-house water connection to flush the toilets.

Table 2: $\quad$ Types of toilet facilities (if $1-2=$ good, otherwise poor).

\begin{tabular}{|l|l|l|l|l|l|l|}
\hline & \multicolumn{2}{|c|}{ Bariga } & \multicolumn{2}{c|}{ Agege } & \multicolumn{2}{c|}{ Ajegunle } \\
\hline Sources & No & $\%$ & No & $\%$ & No & $\%$ \\
\hline 1 WC + Septic & 2 & 4.2 & 5 & 11.1 & 3 & 6.8 \\
\hline 2 Pour Flush & 13 & 27.1 & 15 & 33.3 & 12 & 27.3 \\
\hline 3 Pit Laterine & 28 & 58.3 & 21 & 46.7 & 25 & 56.8 \\
\hline 4 Bush/Refuse Dump & 5 & 10.4 & 3 & 6.7 & 2 & 4.5 \\
\hline 5 None & 0 & 0.0 & 1 & 2.2 & 2 & 4.5 \\
\hline Total & 48 & 100.0 & 45 & 100.0 & 44 & 100.0 \\
\hline
\end{tabular}

In summary, only $31.3 \%, 44.4 \%$ and $34.1 \%$ of the respondents in Bariga, Agege and Ajegunle respectively have access to good toilet facilities.

An average of $80 \%$ of the total number of respondents in all the areas studied do not have access to good drainage facilities as corroborated by figure. Even where there are drainage channels, most of them are uncovered and blocked with refuse, sand and stagnant water which are fast breeding grounds for mosquitoes, the major cause of malaria.

In terms of refuse disposal facilities, an average of $70 \%$ of the respondents in the three communities patronize the local truck pushers who in turn dump the refuse indiscriminately on the roads or near water bodies. These local truck pushers collect refuse from individual households for a paltry sum and carry away the refuse uncovered thereby, allowing some debris to drop on the roads. The result of this is an unsightly environment littered with refuse and causing very offensive odour.

\subsection{Pollution}

The major types of pollution identified in the study area are air and water pollution. The major sources of air pollution as shown in figure 2 are fumes from rickety vehicles, smoke from neighbourhood and foul smell from surroundings. These occur in very high intensities. The three communities show the same pattern of occurrence and intensities. The atmosphere is rarely clean.

Another type of pollution identified is indoor air pollution. Sources of energy for cooking were used to measure this type of pollution. Results from table 3 
show that $56.1 \%, 46.6 \%$ and $63.6 \%$ of respondents in Bariga, Agege and Ajegunle respectively still use poor sources of energy for cooking. Soot from the burning of wood, dung, crop residues and coal for cooking and heating are very irritating and can lead to very acute respiratory diseases especially among women and children. Cooking is done inside the living rooms and this is very hazardous. The situation is worsened by lack of ventilation in the buildings. Lung cancer has also been associated with indoor pollution.

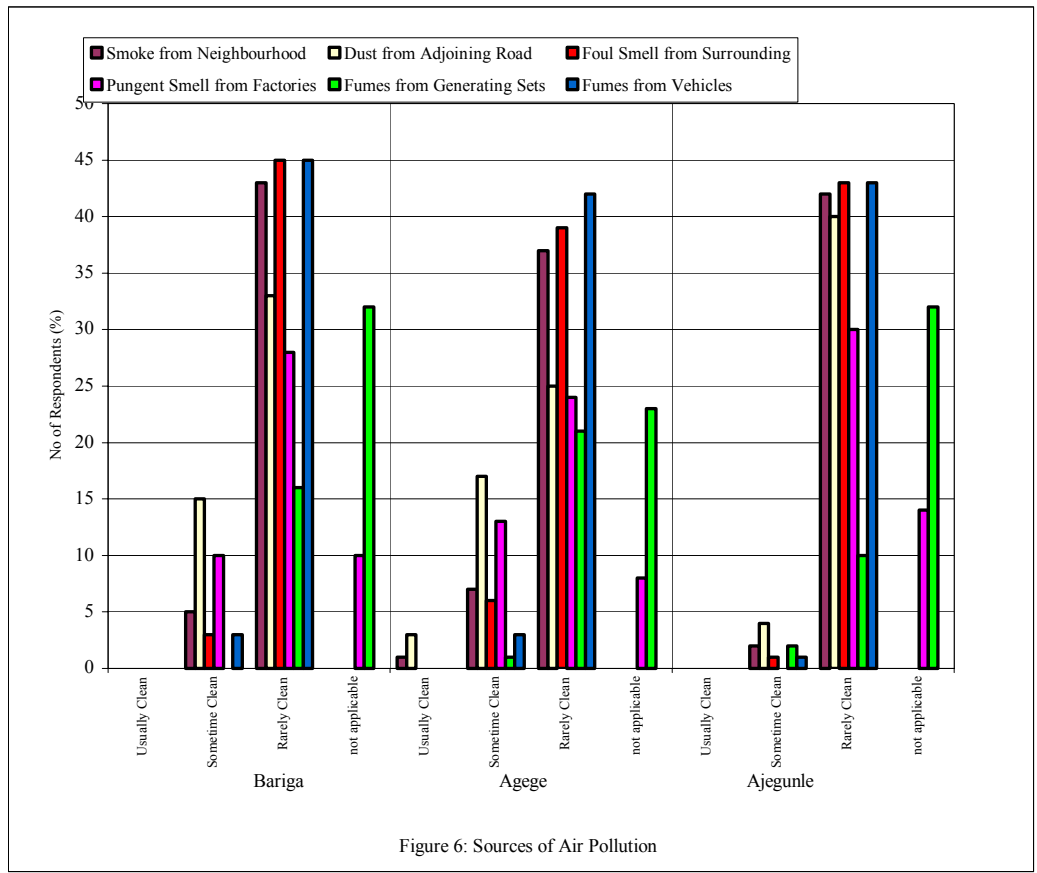

Figure 2: $\quad$ Major sources of air pollution and intensity.

Table 3: $\quad$ Sources of energy for cooking (if 1-2 = good, otherwise poor).

\begin{tabular}{|l|l|l|l|l|l|l|}
\hline & \multicolumn{3}{|l}{ Bariga } & \multicolumn{2}{l|}{ Agege } & \multicolumn{2}{l|}{ Ajegunle } \\
\hline Sources & No & $\%$ & No & $\%$ & No & $\%$ \\
\hline 1 Gas & 3 & 6.3 & 4 & 8.9 & 1 & 2.3 \\
\hline 2 Kerosene & 18 & 37.5 & 20 & 44.4 & 15 & 34.1 \\
\hline 3 Charcoal & 20 & 41.7 & 20 & 44.4 & 23 & 52.3 \\
\hline 4 Firewood & 5 & 10.4 & 1 & 2.2 & 3 & 6.8 \\
\hline 5 Others & 2 & 4.2 & 0 & 0.0 & 2 & 4.5 \\
\hline Total & 48 & 100.0 & 45 & 100.0 & 44 & 100.0 \\
\hline
\end{tabular}

Water pollution from waste water, solid waste dumps and effluents from industrial sources have been found to be a major health threat to residents of the 
study area. This is exacerbated by flooding of most areas of Lagos metropolis usually caused by a combination of human and natural factors. The human factors are as a result of poor wastewater disposal and other sanitation practices while the natural factors include rainfall, flat topography and poor infiltration. All the factors described above are associated with various environmental health diseases as discussed in the next section.

\subsection{Disease pattern in the study areas and their relationship to environmental conditions}

The most prevalent disease in all the communities is malaria, closely followed by diarrhoea. This was reported more by the women and children. Figure 3 describes the situation in the three communities. These are diseases associated with bad environmental conditions. Similarly, deaths related to environmental conditions recorded more than 60\% in each of the communities. Questions asked on child mortality (children below 5 years) confirmed that malaria and diarrhoea were the major killer diseases. Records from each of the three hospitals sampled corroborated results from the primary data.

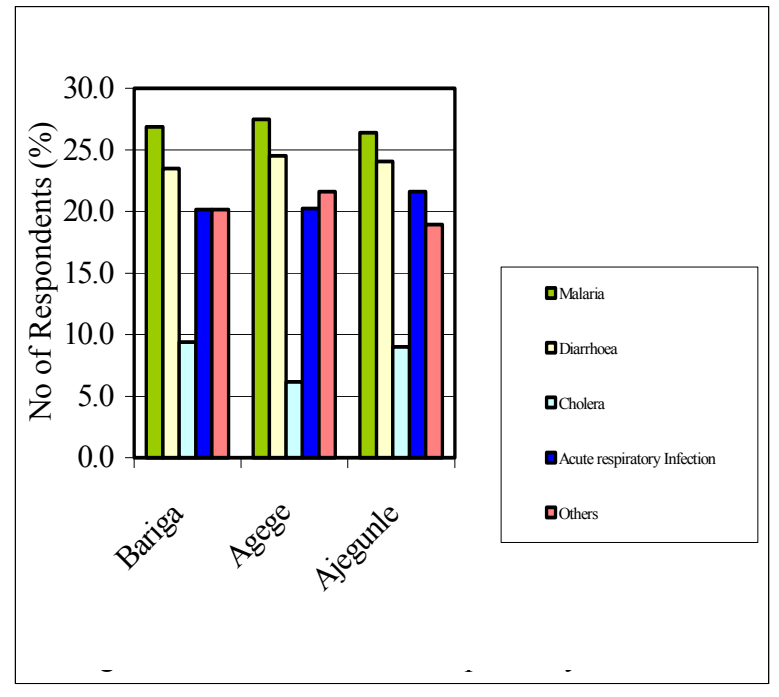

Figure 3: $\quad$ Prevalent diseases in the past one year.

The correlation analysis done to see the relationship between environmental conditions and health of residents show a significant association, therefore, Hi is accepted at $95 \%$ significant level. Table 4 shows the correlation matrix. There is a significant relationship between death in the past one year and quality of water and drainage facilities. The relationship between mortality and all the environmental factors is negative. Another correlation matrix between environmental factors and prevalent diseases show a high correlation between malaria and diarrhoea with environmental factors. 
The summary of all the above results confirm that low income communities where most of the poor live suffer from environmental health hazards. It has also shown that women and their children are most vulnerable.

Table 4: Relationship between environmental factors and health conditions.

\section{Correlation Matrix}

\begin{tabular}{|l|c|l|l|l|l|l|l|}
\hline & $\begin{array}{l}\text { Death in } \\
\text { the past } \\
\text { one year }\end{array}$ & $\begin{array}{l}\text { Good } \\
\text { source } \\
\text { of water }\end{array}$ & $\begin{array}{l}\text { Bad } \\
\text { source } \\
\text { of water }\end{array}$ & $\begin{array}{l}\text { Good } \\
\text { toilet } \\
\text { facilities }\end{array}$ & $\begin{array}{l}\text { Poor } \\
\text { toilet } \\
\text { facilities }\end{array}$ & $\begin{array}{l}\text { Good } \\
\text { drainage }\end{array}$ & $\begin{array}{l}\text { Poor } \\
\text { drainage }\end{array}$ \\
\hline $\begin{array}{l}\text { Death in } \\
\text { the past } \\
\text { one year }\end{array}$ & 1.000 & -.809 & .809 & -.332 & .332 & -.995 & .995 \\
\hline $\begin{array}{l}\text { Good } \\
\text { source of } \\
\text { water }\end{array}$ & -.809 & 1.000 & -1.000 & .823 & -.823 & .863 & -.863 \\
\hline $\begin{array}{l}\text { Bad source } \\
\text { of water }\end{array}$ & .809 & -1.000 & 1.000 & -.823 & .823 & -.863 & .863 \\
\hline $\begin{array}{l}\text { Good toilet } \\
\text { facilities }\end{array}$ & -.332 & .823 & -.823 & .1000 & -1.000 & .423 & -.423 \\
\hline $\begin{array}{l}\text { Poor toilet } \\
\text { facilities }\end{array}$ & .332 & -.823 & .823 & -.1000 & 1.000 & -.423 & .423 \\
\hline $\begin{array}{l}\text { Good } \\
\text { drainage }\end{array}$ & -.995 & .863 & -.863 & .423 & -.423 & .1000 & -1.000 \\
\hline $\begin{array}{l}\text { Poor } \\
\text { drainage }\end{array}$ & .995 & -.863 & .863 & -.423 & .423 & -.1000 & 1.000 \\
\hline
\end{tabular}

3 observations were used in this computation.

\section{Conclusion}

This study has identified both the traditional and modern environmental health risk factors faced especially by residents of low income communities in Nigeria as epitomized in Metropolitan Lagos. The following are some of the policy implications or recommendations of this paper.

Though effective and enforceable environmental policies are difficult to develop and implement in many sub-Saharan countries including Nigeria, it appears a major factor if the country must be environmentally secure. The state government should enforce the banning of importation of used vehicles for over five years. This will reduce the menace of air pollution. The production capacity of the Lagos State water Corporation (LSWC), the sole organization in charge of water supply should be increased to make potable water available to more users. The three communities studied have already been selected for upgrading. The implementation of this plan has become apt and it is hoped that the drainage, refuse disposal and flooding problems will be taken care of.

There is a need to prepare a good plan which will ensure that resources will be managed well and urban residents will breathe cleaner air, drink purer water, and lead healthier lives. Such a good plan should involve a clear understanding of problems; improved regulation; participation of all stakeholders; the use of suitable technologies; and realistic financing options 
It has been established that the poor are the ones mostly environmentally at risk Investments in the human capital of the poor can also strengthen their ability to combat environmental degradation of which they are victims. Healthcare facilities should be made accessible to the vulnerable group. The Primary health care efforts of the federal, state and local governments should be intensified. This will make health care affordable to the poor.

However, while the policies mentioned above are desirable, there are some inexpensive strategies that can be employed to combat these threats. Washing hands with soap or ash before preparing food, before meals and after defecating significantly reduces the risk of diarrhea, even when the overall quantity of water available is limited. Ensuring safe sanitary facilities and the use of separate latrines for boys and girls encourages latrine use and reduces disease transmission. Proper waste management and the relocation of waste dumps away from human settlements protect children from scavenging and exposure to hazards. Safe water storage in the home and simple treatment when water quality is in doubt leads to proven health benefits. Good ventilation in homes, improved cooking stoves and clean household fuels decrease indoor air pollution and the incidence of acute respiratory infections. Screening doors, windows and eaves, along with the use of insecticide-treated mosquito nets is very effective protection against malaria.

Finally, environmental education should be a must in the curriculum of schools from post primary level.

\section{References}

[1] United Nations Development Programme (UNDP). Human Development Report: Nigeria 2000/2001 Millennium Edition. UNDP, Abuja.2001.

[2] World Health Organization (WHO) Water, Sanitation and Hygiene links to Health: facts and figures. 2004. http://www.who.int /water_sanitation_health/en/factsfigures04.pdf

[3] Federal Environmental Protection Agency. Nigeria Country Analysis Brief: Environmental issues. http://www.eia.doe.gov/cabs/nigenv.html. 2003.

[4] Iwugoh, K.O., Arcy, B.O. \& Andoh, R., Aspects of land-based Pollution of an African coastal Mega-city of Lagos. Diffuse Pollution Conference Dublin Poster Papers, pp. 14-123, 2003.

[5] Lagos State Government. Report of the Second Lagos State Economic Summit, Ehingbeti. Ministry of Economic Planning and Budget, Ikeja, Lagos. 2001.

[6] Federal Office of Statistics, Abuja, Nigeria. 2001.

[7] United States Agency for International Development (USAID) The challenges and possibilities facing the Nigerian environment. 2002.

[8] World Resources Institute [WTI] World Resources 2000-2001. Washington DC. http://pubs.wti.org/pubs_pdf.cfm

[9] World Bank. Nigeria: Poverty in the midst of plenty: the challenge of growth with inclusion. Report No. 14733.1996 
[10] Brundtland, H. G., A paper delivered at the launch of World Health Day, New Delhi, India. 2003.

[11] Akhtar, R., Introduction (chapter1). Health and Disease in Tropical Africa, ed. Akhtar, R Harwood Academic Publishers: London, Paris New York, pp. 1-6, 1987

[12] Adedoyin, M., \& Watts, S., Child health and child care in Oke-ile: An Indigenous area of the city of Ilorin, Nigeria. Social Science and Medicine. 29(12) pp.133-34, 1989.

[13] Egunjobi, T.O., Environmental Health Situation in Ibadan City (chapter 14) ed. Akhtar, R., Urban Health in the Third World. A. P. H Publishing Corporation: New Delhi, pp.301-317, 2002. 